\title{
An Analysis on Public Expenditure Policy for Employment Training: Evidence from China
}

\author{
Xiaoqing Xie \\ School of Public Administration, China University of Geosciences, Wuhan, 430074, China \\ email: cathywh@163.com
}

Keywords: Public Expenditure Policy; Employment Training; Employment Promotion

\begin{abstract}
Presently China's employment policy is facing severe challenges and difficulties. China had amendment policies about labor force but unfortunately they are having a deficiency of skills due to lack of training programs. This paper discussed the employment structure of China and Government's public expenditure for employment training in China. This study analyzed the current policy of employment and its existing problems, the importance of employment training, and public expenditure for employment and related fundamentals and proposed the policy suggestions to perfect China’s public policy for employment training.
\end{abstract}

\section{Introduction}

Social productive forces have been greatly liberated by reform and opening up for 30 years to successfully endeavor the transition from a planned economy to a market economy and hence employment has also made avid achievements. However, with the development of urbanization, the explicit trends of hidden unemployment have become more and more affluent. Due to some reasons like financial crisis and adjustment of the economic structure leads to bizarre circumstances on the employment of China. To resolve rigorous employment altercations of China effectively to promote sustained development of economy has become requisite ingredient which needs to be fully addressed by scholars. Henceforth, conspicuous understanding of the status quo of China's employment problem and quest the clear stance of public policy and promoting employment is the exigent to manipulate the implications of employment.

Public expenditure policy is supremacist tool for the state's macro regulation and control and there is a mass correlation between public expenditure policy and employment level. Public expenditure policy influence aggregate demand and aggregate supply as well as economic cum industrial structure and thus it will cause changes in aggregate employment and employment structure. Henceforth, conspicuous understanding of the status quo of China's employment problem and quest the clear stance of public policy and promoting employment is the exigent to manipulate the implications of employment.

Expatiating facts and figures that the strategic approach to human resource development is prerequisite in the globalization era and the continuous training of employees is essential. Ingeniously the existence of employees at the organizational level who do not manage to professionally adapt to the changes occurring in the conduct of activities is a cumbersome altercations for managers (Manole, 2011). Laura Alonso-Díaz, etc (2014) design, implement and evaluate a program for educational excellence, based on the integrated use of virtual platforms and synchronous virtual classrooms in employment training. Pierre-Jean Messe, etc (2014) use a difference-in-differences approach to study the effects of firing taxes on firms' incentives to sponsor training and the effects tend to be higher among low-skilled workers. Corollary, professional training is prerequisite element of strategic human resource management along with other components: talent development, performance development, leadership development and organizational development (Hu, 2007).

Contemplating current situation of China's employment is eye-catching for many scholars of china as well as from other countries in the world due the immense economic growth of china from a fiscal point of view to explore measures to ease the employment pressure. Jia Kang (2003) 
opinions that Fiscal must have strategic thinking to solve the altercations of employment tacitly, and the strategic speculation should include financial support for the development of labor-intensive enterprises and increasing employment opportunities in rural regions. Su Ming(2008) proposed that the government should adjust the structure of fiscal expenditure to increase investment levels of government funding in vocational training, strengthen vocational education and training to optimize education and training institutions to improve the quality of training and the employ-ability of workers. Zhao Man, Gu Yonghong (2009) argued to improve the efficiency of employment expenses utilization and it is necessary to the characteristics of the employment expenses utilization to develop employment expenditure performance management approach in the use of financial resources. Wang Zhenyu, Lian Jiaming (2009) expatiates that employment has become a primary task facing China's economic and social development, for this the relevant fiscal policies that need to be adjusted urgently for to increase employment supporting measures. Zhu Cuiping, Jiang Zhihua (2010) proposed to accelerate the construction of the public finance system, raise fiscal expenses to increase employment and entrepreneurship training and human capital investment and to establish supportive employment services system. Gu Weiwei (2013) discussed that the government should increase investment on human resources of rural migrant workers.

This manuscript is based upon the statistical data of aggregate of public expenses of employment and social security, GDP and employment persons from 2007 to 2014 and the documents issued by central government in China, discusses the current situation of China's public expenses policy in employment training and policy implications.

\section{China's Public Expenditure and Management for Employment Training}

In order to promote employment most of countries in the world have set up public expenditure to support employment and it is generally called "employment services expenses" and called "employment expenses" in China. In present employment expenses haven't been allocated individually from public expenses but disbursed out of "social security subsidy expenses-employment subsidy” in China since the beginning of 2003. From 2003-2006, the central government and local government had arranged the accumulative total of special re-employment transfer payment funds about 184 billion yuan. In 2007, the central government continues to arrange employment subsidies 24.5 billion yuan. In 2009 the central government allocated 42.02 billion yuan of employment funds and up to 66.7\% over in 2008 (Zhao Man, Gu Yonghong, 2009). Public employment expenses is the core financial resources and basic supporting strength for the sustainable employment policy and adjusting the scale and direction of public expenditure to increase employment, therefore, public employment expenses has made important contributions to ease the employment pressure.

\section{(1)The Current Situation of Public Employment Expenditure in China}

Compendiously the level of public expenditure on the promotion of employment is difficult to meet the need and to deal with the severe employment situation. On the other hand, China's public expenses on employment accounts for a low ratio of GDP. In general, labor market programs in the majority of OECD countries accounted for more than 3\% and 1\% of public expenditure and GDP respectively. while the employment subsidies and subsidies and grants for living expenses of workers laid off from state-owned enterprises only account for $1.06 \%$ of the public expenditure and 0.19\% of GDP in 2004 in China (Liu Yanbing, Ma Yongtang, 2007). China's public expenditure in employment primarily focus on unemployment security and subsistence allowances for the urban poor and employment training funding is clearly insufficient. However the public expenditure can only play a temporary role in cushion unemployment and at the same time by increasing employment training fund long-term problems can be solved. In the history of China the total public expenditure of employment and social security from 2007 to 2014 increased to 1596.89 billion yuan in 2014 from 544.72 billion Yuan in 2007, corresponding to the growth of GDP from 26801.94 billion yuan in 2007 to 63591.00 billion yuan in 2014, the whole community working population 
from 753.2 million persons in 2007 to 772.5 million persons in 2014(see Table 1). Evidently the unemployment problems were alleviated in some extent which is closely related to the proactive fiscal policy. Therefore, the multiplier effect of public expenditures is not only to promote the economic growth, but also have a significant increase in total employment.

Table 1. The Increase Statement of China's Public Expenditures, GDP and Employment Population in 2007-2014

\begin{tabular}{|c|c|c|c|c|c|c|}
\hline Year & $\begin{array}{c}\text { Fiscal Expenses } \\
\text { of Employment } \\
\text { and Social } \\
\text { Security } \\
\text { (billion yuan) }\end{array}$ & $\begin{array}{c}\text { Growth Rate of } \\
\text { Fiscal Expenses of } \\
\text { Employment and } \\
\text { Social Security } \\
(\%)\end{array}$ & $\begin{array}{c}\text { GDP } \\
\text { (billion } \\
\text { yuan) }\end{array}$ & $\begin{array}{c}\text { Growt } \\
\text { h Rate } \\
\text { of } \\
\text { GDP } \\
(\%)\end{array}$ & $\begin{array}{c}\text { Employme } \\
\text { nt } \\
\text { Population } \\
\text { (million } \\
\text { persons) }\end{array}$ & $\begin{array}{c}\text { Growth } \\
\text { Rate of } \\
\text { Employmen } \\
\text { t Population } \\
(\%)\end{array}$ \\
\hline 2007 & 544.72 & $/$ & 26801.94 & $/$ & 753.2 & $/$ \\
\hline 2008 & 680.43 & 25.91 & 31675.17 & 18.18 & 755.6 & 0.32 \\
\hline 2009 & 760.67 & 11.79 & 34562.92 & 9.12 & 758.3 & 0.36 \\
\hline 2010 & 913.06 & 20.03 & 40890.30 & 18.31 & 761.1 & 0.37 \\
\hline 2011 & 1110.94 & 21.67 & 48412.35 & 18.40 & 764.2 & 0.41 \\
\hline 2012 & 1258.55 & 13.29 & 53412.30 & 10.33 & 767.0 & 0.37 \\
\hline 2013 & 1449.05 & 15.14 & 58801.88 & 10.09 & 769.8 & 0.37 \\
\hline 2014 & 1596.89 & 10.20 & 63591.00 & 8.14 & 772.5 & 0.35 \\
\hline \multicolumn{7}{|c|}{ Sources: The data is from the Website of National Bureau of Statistics of China, } \\
\hline
\end{tabular}

\section{(2)The Division of Responsibilities and Management of China's Employment Training}

Tacitly the genre elements of employment training, China's public employment training is managed by different departments as the main departments are human resources, agriculture, education, science and technology, others such as finance, the Woman's Federation, Communist Youth League, also have involved. Although from the formality point of view many management documents of public employment training program is issued jointly by several departments and many local governments have also established public employment training coordinating organizations but in the actual operation the management and operation of these training programs present urban-rural division and develop their own planning and system. Only the rural labor force training involves more than ten administrative departments. Each of Public Employment Training Project management departments has its own training tasks and channels and has made its own training funds standards and their utilization method thus it causes the dispersion of funds, multifarious administrations, serious selfish departmentalism, at the meanwhile these all increases the operation cost of organization and resulting in the loss of institutional obstacles.

\section{Discussion}

\section{(1)Public Employment Training Fiscal Investment and Structure}

In China, fiscal investment on employment training is inadequate evidently; the low proportion of employment expenses account for total fiscal expenditure, especially local financial investment on employment is too slight. Training education investments and the labor force quality are closely connected and the portion of investment for training education is also very low. Therefore, it could be the reason of low lack of expertise by labor worker even had a large number of labors, due to this reason sometime it is difficult to reach the final goal of industrial development.

\section{(2)Employee's Training Investment System}

There are also some problems in employment training in China like training institutions are no 
standardized, training costs are too high, and training contents did not fulfill the requirements and demands for development of economic and society. In the worldwide, employment skills and training programs are carried out generally under the government's plan and for to invest in this sector the government establish vocational institutions and also provide funds to universities, research institutions and training institutions, but as per comparison between China and rest of World is different. Currently, we can see in the present system of training for rural workers still some problems are occurring in management and disbursement of employment funds. China's government allocated the funds in public employment training are temporary, flexible and decentralized state, which leave effects on co-ordination and training funds.

\section{(3)Employee's Training Subsides}

There is not a unified standard of employment training subsidy and the subsidy standard is too low. The low training subsidy standard also affect enthusiasm and training effect of the training base. For example, from 2007, A document was issued formally by Wuhan government that normal work training and the third industry jobs skills training provided by "Sunshine" employment training project must be more than one month training in school and practice 1-2 months, so it put forward higher requirements for training quality. But as a result of rising prices and most peasants in Wuhan city are reluctant to pay and attend training programs, it lose the training quality in institutions due to lose in money (Hu Zaiguo, 2009).

\section{(4)Investment Body}

In China, employment training in city and town is invested by the finance department basically, these both increased the fiscal pressure of the state and local, also affects the efficiency of employment training. The enterprise is also the important beneficiary of employment training, and should pay certain training inputs. "Sunshine" employment training project implements the principle that the government and workers should share the burden of training expenses. Workers are the main body and direct beneficiary of employment training and according to the principle of "he who benefits bears the expense", the overwhelming majority of training cost should be borne by workers. However, workers' income is very poor, and under the situation of the production cannot be effectively solved, to increase employment training investment decided by the expected income is not realistic. Nowadays, multi-side investment mechanism hasn't been formed in the field of public employment training in China.

\section{Policy Implications}

"Okun's law" demonstrates that the economic growth and employment has a positive correlation, but the economic growth and unemployment has a negative correlativity. According to the data of National Bureau Statistics of China, in the 1980s, the increase of one percentage point of the GDP will increase 2.4 million jobs, but since the 90 s, only increase 0.7 million jobs. The related research shows that the increase of one percentage point of the GDP will increase about 1 million jobs (Zhu Cuiping, Jiang Zhihua, 2010). In order to resolve unemployment, the government should pay full attention to the role of economic growth, Keep a certain range of investment and economic growth and continue to implement the proactive fiscal policy and a moderately easy monetary policy, maintain the continuity and stability of the policy and the implementation of the policies. Therefore, on the base of our paper discussion and study this paper provides some policy suggestions are as the following:

\section{(1)Need to increase the budget for training program by local and central government bodies}

Low range of employment training not only due to lack of investment by enterprise and individual but also the one reason is due to the low enthusiasm of local government's investment, so 
the training costs should be shared according to the principle of cost-benefit symmetry. The government should continue to increase the investment on public employment training.

\section{(2)Monitoring of employment training budget performance and training expenses}

In December 2008, the ministry of finance and the Ministry of Human Resources and Social Security issued the notice on the use and management of special funds of employment training and the related problems. The people's governments at or above the county level according to the employment situation and employment work targets, in the fiscal budget arrange employment special funds to promote employment.

\section{(3)Establish an incentive mechanism for multi-side participation in employment training}

According to the principle of efficiency, fairness, ability and macro-control, admixture accommodation is a scientific and realistic choice for public employment training in China. Thus, an incentive mechanism should be set up to lead multi-side participation in employment training, and a new scheme of employment training is given, including scientific training concept, adequate training fund, a well-conceived plan, effective methods and technology, certain training evaluation system and encouragement.

\section{(4)Working out index system for monitoring and evaluation of employment training expenditures performance, the rate of employment as the main index}

The purpose of public employment training is to help the unemployed realize employment, so taking the rate of employment as main indicators of public employment training expenditure performance evaluation conforms to the public employment training purpose and also has strong suitability. Meanwhile, it is difficult to supervise the process of public employment training, the measurability of process evaluation index is poor, the results indicators, such as the rate of employment have a strong measurability.

For the smooth run of training program for the betterment of employment we need to establish good and effective organizations and according to the characteristics of employment training expenses, employment training expenditure evaluation measures need to enhance the awareness of fund allocations, and gradually build a tracing mechanism of employment training expenses efficiency, improve the mechanism of financial fund management and utilization.

\section{Acknowledgement}

This research is funded by China's Ministry of Education project of humanity and social sciences research (No. 12YJA630156).

\section{References}

[1] Manole, C., Alpopi, C., Colesca, S.E.. The Strategic Role of Human Resources Development in the Management of Organizational Crisis[J]. Economic Magazine, Management Series, A.S.E. Ed, Bucharest, 201114 (1) 207-221.

[2] Laura Alonso-Díaz, Prudencia Gutiérrez-Esteban, Rocío Yuste-Tosina. Training for employment through virtual training models: description of a research project [J]. Procedia - Social and Behavioral Sciences, 2014 (139) 456-463.

[3] Pierre-Jean Messe, Bénédicte Rouland. Stricter employment protection and firms' incentives to sponsor training: The case of French older workers [J]. Labour Economics, 2014 (31) 14-26.

[4] Hu, P. Theorizing Strategic Human Resource Development: Linking Financial Performance and Sustainable Competitive Advantage. In F.M., Nafukho \& T. Chermak (Eds.), Proceedings of the 
Academy of Human Resource Development 2007, International Research Conference, Fayetteville, AR: University of Arkansas, 2007.

[5] Jia Kang. Thaking Effective Measures to Alleviate Employment Pressure[J]. China State Finance, 2003 (2) 10.

[6] Su Ming. Research on the Financial of Practical Problems in China. Economic Science Press, 2008.

[7] Zhao Man, Gu Yonghong. Research on the Performance of Financial Expenditure and Policy Suggestions [J]. China State Finance, 2009 (19) 54-55.

[8] Wang Zhenyu, Lian Jiaming. Research on the Current Countermeasures of Finance and Taxation [J]. Taxation Research, 2009 (5) 18-23.

[9] Zhu Cuiping, Jiang Zhihua. Research on the Effect and Policy Suggestion of Fiscal Expenditures on Employment [J]. Journal of Yunnan Finance and Trade Institute, 2010 (3) 53-61.

[10] Gu Weiwei. On the Role of Government in Employment Support of Migrant Workers [J]. Science, Economy, Society, 2013 (2) 76-80.

[11] Liu Yanbing, Ma Yongtang. Comparative Research on Public Finance Investment in Employment [J]. China Labor, 2007 (6) 29-32.

[12] Hu Zaiguo. An Analysis of the Cause and Means to Solve the Problem on Absorbing Students of Employment Training Provided by Sunshine Project and Rain and Dew Plan, ttp://www.Hbagri.gov.cn/yg/hrregister_rule.asp, 2009. 